\title{
Treatment of systemic lupus erythematosus
}

\section{SUMMARY}

Systemic lupus erythematosus should be suspected in individuals with one or more classic symptoms. Diagnosis is made clinically and supported by serology.

Reducing sun exposure is central to the management of lupus.

Hydroxychloroquine is first-line treatment unless contraindicated and is useful in almost all manifestations of lupus. Other treatments are titrated against type and severity of organ involvement.

Monoclonal antibodies have a limited role in the management of lupus.

\section{Introduction}

Systemic lupus erythematosus (also known as lupus) is a chronic, relapsing-remitting autoimmune disease characterised by autoantibody production. It may present at any stage of life, but is most common in women of childbearing age, with a female to male ratio of 9:1. Lupus has a wide spectrum of presentations, including skin, psychiatric and kidney manifestations.

\section{When to suspect lupus}

Lupus should be considered in any individual with one or more typical manifestations, but especially women of childbearing age. Classic symptoms include photosensitive rash, mouth ulcers, small joint arthritis, or unexplained cytopenias and venous or arterial clotting. Serositis and neurologic involvement are observed less commonly (Box).

\section{How to confirm diagnosis}

The variable manifestations of lupus make diagnosis difficult and serology can be useful (see Box). Almost all patients (99\%) have antinuclear antibodies at diagnosis. However, they are nonspecific and present in approximately $5 \%$ of the healthy population at titres of $1: 320 .{ }^{2}$ More specific for lupus is the presence of anti-double-stranded DNA antibodies, particularly when detected by the radionucleotide Farr assay. These are observed in approximately $70 \%$ of patients with lupus. ${ }^{3}$ Anti-Smith antibodies are uncommon but specific for lupus and associated with nephritis and cytopenias. ${ }^{4}$ Antiphospholipid antibodies are found in $40 \%$ of patients and are classically associated with an elevated risk of thrombosis and miscarriage. ${ }^{5}$ Antibodies against the extractable nuclear antigens $\mathrm{Ro}(\mathrm{SSA}), \mathrm{La}(\mathrm{SSB})$ and ribonuclear protein are common but nonspecific in the diagnosis of lupus. Antinuclear antibodies combined with lupus-specific antibody positivity can support the diagnosis. These are incorporated in the Systemic Lupus International Collaborating Clinics diagnostic criteria (Box). ${ }^{1}$

\section{Pathogenesis}

The pathogenesis of lupus is a composite of complex genetic risk and environmental influences. While immunologic abnormalities ranging from complement to B-cell dysregulation are reported, increased type 1 interferon activity is observed in $85 \%$ of patients at any point in time. ${ }^{6}$ This is central to the disease. Reflecting this complex pathogenesis, several distinct biologic pathways have been targeted in the treatment of lupus.

\section{Management of lupus}

The management of lupus includes three goals:

- $\quad$ preventing flares and their symptomatic impact

- reducing chronic accumulation of organ damage

- minimising toxicity from immunosuppression.

All patients should minimise sun exposure and use hydroxychloroquine unless contraindicated. measures, antiproliferative immunosuppressants and corticosteroids are effective. The choice of antiproliferative is influenced by the organ involved. Cyclophosphamide is used for severe life- and organthreatening lupus. Biologic drugs have a limited role but drugs such as rituximab may be used for manifestations refractory to other treatments.

\section{Non-drug approaches}

Ultraviolet exposure can flare both cutaneous and systemic symptoms such as arthritis. Sunscreens (SPF 50+) should be used as well as avoiding exposure during peak hours. ${ }^{7}$

Smoking cessation may help with treatment-resistant skin lesions. ${ }^{8}$ It may also mitigate the elevated cardiovascular risk associated with lupus. ${ }^{9}$ For lupus activity that is resistant to these

\section{Kathryn P McKeon \\ Research fellow?}

Simon H Jiang

Consultant nephrologist

Postdoctoral fellow ${ }^{2}$

' Department of Renal Medicine, The Canberra Hospital

2 Department of Immunology and Infectious Diseases, John Curtin School of Medical Research, Australian National University

Canberra

\section{Keywords}

corticosteroids,

hydroxychloroquine,

immunosuppressants,

systemic lupus

erythematosus

Aust Prescr 2020;43:85-90 https://doi.org/10.18773/ austprescr.2020.022 


\section{Box Diagnostic criteria for systemic lupus*}

\section{Clinical criteria}

Acute cutaneous - lupus malar rash, bullous lupus, toxic epidermal necrolysis variant of lupus, maculopapular lupus rash, photosensitive lupus rash

Chronic cutaneous - discoid lupus rash, hypertrophic (verrucous) lupus, lupus panniculitis, mucosal lupus, lupus erythematosus tumidus, chilblains lupus, discoid lupus Oral or nasal ulcers - palate, buccal, tongue, or nasal in the absence of other causes Non-scarring alopecia - in the absence of other causes

Arthritis - synovitis involving 2 or more joints, characterised by swelling or effusion or tenderness in 2 or more joints and at least 30 minutes of morning stiffness

Serositis - typical pleurisy for more than one day, pleural effusions, pleural rub or typical pericardial pain for more than one day, pericardial effusion, pericardial rub or pericarditis by ECG

Renal involvement - urine protein:creatinine ratio or 24-hour urine protein with $>500 \mathrm{mg}$ protein/24 hours or red cell casts

Neurological symptoms - seizures, psychosis, mononeuritis multiplex, myelitis, peripheral or cranial neuropathy, acute confusional state

Haemolytic anaemia - in the absence of other causes

Leucopenia - in the absence of other causes

Thrombocytopenia - in the absence of other causes

\section{Immunological criteria}

Antinuclear antibodies

Anti-dsDNA antibodies - above reference range (or $>2$-fold if tested by ELISA)

Anti-Smith antibodies

Antiphospholipid antibodies - positive lupus anticoagulant, false-positive rapid plasma reagin test, medium- or high-titre cardiolipin antibody, positive anti-b2-glycoprotein

Low complement $\mathrm{C3}, \mathrm{C4}, \mathrm{CH} 5 \mathrm{O}$

Positive Direct Coombs test - in the absence of haemolytic anaemia

* For a positive diagnosis, patients must have 4 or more of the listed criteria, with at least 1 clinical and 1 laboratory criterion

dsDNA double-stranded DNA

ELISA enzyme-linked immunosorbent assay

Source: reference 1 doses (400 mg daily). ${ }^{16}$ In addition to improving skin symptoms, hydroxychloroquine reduces flares of systemic lupus ${ }^{17}$ and lupus nephritis. ${ }^{18}$ It also lowers cholesterol and thromboembolic risk in patients with antiphospholipid antibodies. ${ }^{19,20}$ Consequently, sustained hydroxychloroquine therapy minimises accrual of organ damage ${ }^{21}$ and glucocorticoid-induced osteoporosis, and improves overall survival. ${ }^{22}$

The major complications of hydroxychloroquine therapy are ocular. Transient and reversible corneal deposits occur in about $10 \%$ of people. ${ }^{23}$ Irreversible retinopathy can also develop and typically manifests as visual disturbances, photophobia or light flashes. The risk of retinal toxicity is cumulative and may be as high as $20 \%$ at 20 years with recommended hydroxychloroquine doses. ${ }^{24} \mathrm{~A}$ maximal daily hydroxychloroquine dose of less than $5 \mathrm{mg} / \mathrm{kg}$ (up to $400 \mathrm{mg} /$ day) is recommended, along with regular screening by an ophthalmologist to detect toxicity before visual changes (Table 1). ${ }^{24-26}$ Less common adverse effects include cardiac, cutaneous and neuropsychiatric manifestations. ${ }^{27}$ Hydroxychloroquine is safe to use in pregnancy and should be continued. ${ }^{28}$

\section{Corticosteroids}

Almost all patients will be treated with corticosteroids at some point. ${ }^{29}$ They are effective in controlling systemic lupus but their sustained use is limited by substantial toxicity. Corticosteroids are used transiently to control systemic disease flares or when disease activity cannot be controlled by other drugs alone. Due to toxicity, they should never be used on their own.

The adverse effects are dose-dependent and include an increased risk of infection, cancer, osteoporosis and avascular necrosis, steroid-induced diabetes, accelerated atherosclerosis and mood disturbances. ${ }^{30}$ Cardiovascular risk is significantly increased in lupus and the use of corticosteroids increases this further. ${ }^{31}$ Indeed, no study has established a safe lowest dose in systemic lupus so when possible they should be withdrawn. ${ }^{32}$

The toxicity of corticosteroids needs to be balanced against the threat of organ injury if they are not used. For mild disease, lower doses are often sufficient. High doses are typically reserved for debilitating or life-threatening involvement such as lupus nephritis or neuropsychiatric lupus (Table 2). ${ }^{33}$ Once disease remission is achieved, the dose should be tapered.

For cutaneous lesions, topical corticosteroids are the mainstay of treatment. Higher potency creams have superior efficacy over low-potency creams. ${ }^{34}$ However, they increase the risks of telangiectasia and skin atrophy and are used intermittently depending on the severity and location of the lesions. Topical steroids are useful for mouth ulcers but increase the risk of candidiasis. 
Table 1 Monitoring for patients receiving lupus treatments

\begin{tabular}{ll}
\hline Drug & Monitoring \\
\hline Hydroxychloroquine & Baseline fundal exam of the eye, then annual screening after 5 years treatment ${ }^{24}$ \\
\hline Corticosteroids & $\begin{array}{l}\text { Baseline and annual bone densitometry } \\
\text { Annual diabetes check } 3,25\end{array}$ \\
& Periodic ophthalmology review for cataracts and glaucoma \\
\hline Azathioprine & TMPT activity before starting treatment \\
& Full blood count at 2-4 weeks for 2-3 months, then every 3 months \\
\hline Methotrexate & Full blood count and liver function test every 2-4 weeks for 3 months, then every \\
\hline 2-3 months until 6 months. Monitor every 3 months when patient is stable & Full blood count at 2-4 weeks, then every 3 months \\
\hline Mycophenolate & Full blood count every 2 weeks for a month, then monthly \\
\hline Cyclophosphamide & Optional: check CD19+ B cells to confirm depletion \\
\hline Rituximab &
\end{tabular}

TMPT thiopurine methyltransferase

Table 2 Steroid doses and indications in lupus

\begin{tabular}{llll} 
EULAR grading & $\begin{array}{l}\text { Dose: prednisolone } \\
\text { equivalent }(\mathbf{m g})\end{array}$ & Typical indications & Duration and tapering \\
\hline Low dose & $<7.5$ & Maintenance & $\begin{array}{l}\text { If starting on low dose, give for } \\
\text { 2-4 weeks. Tapering not required }\end{array}$ \\
\hline Medium dose & $7.5-30$ & $\begin{array}{l}\text { Mild disease: cutaneous, } \\
\text { musculoskeletal, haematological, } \\
\text { or constitutional symptoms }\end{array}$ & Medium-high dose for 2-4 \\
& & & weeks then taper over 1-2 \\
migh dose & $30-100$ & Induce remission of severe disease &
\end{tabular}

EULAR European League Against Rheumatism

Source: reference 33

\section{Antiproliferative drugs}

Three antiproliferative immunosuppressants are primarily used in systemic lupus - azathioprine, methotrexate and mycophenolate. For non-renal manifestations such as arthritis and rash where hydroxychloroquine or topical corticosteroids are insufficient, methotrexate is effective. ${ }^{35}$ While evidence is stronger for methotrexate, azathioprine is also useful and has the benefit of being safe in pregnancy. Thiopurine methyltransferase activity should be tested before azathioprine is used to avoid bone marrow suppression in patients with a deficiency.

Mycophenolate is effective in non-renal disease that is refractory to corticosteroids, ${ }^{36}$ and is superior to azathioprine. ${ }^{37}$ However, it is contraindicated in pregnancy. For systemic lupus with kidney involvement, mycophenolate is superior to azathioprine so it is first-line maintenance therapy when tolerated. ${ }^{38}$

\section{Cyclophosphamide}

Cyclophosphamide is an alkylating drug that is beneficial in treating severe lupus. Oral regimens result in higher cyclophosphamide exposure and carry a greater risk of infection and bone marrow suppression than the intravenous preparation. High-dose mycophenolate is as effective as cyclophosphamide in controlling aggressive nephritis and is increasingly used as first-line therapy ${ }^{38}$ given the lower rates of hair loss and infertility. 


\section{Biologic drugs}

A range of new biological therapies has been investigated in patients with lupus. Many have not shown significant benefit to date. ${ }^{39-48}$

\section{Rituximab}

Rituximab is a B-cell depleting antibody against CD20. Despite initial reports of excellent responses to this drug, trials have failed to show a benefit in nonrenal ${ }^{39}$ and renal lupus. ${ }^{40}$ However, it continues to be used in refractory disease and registry data suggest a benefit. ${ }^{49,50}$

\section{Belimumab}

Belimumab antibody inhibits B-cell activating factor (BAFF). This target has shown significant pre-clinical promise given its role in promoting autoreactive B-cell activation and proliferation. ${ }^{51}$ Two multicentre trials, BLISS-52 ${ }^{43}$ and BLISS-76, ${ }^{44}$ assessed the efficacy of belimumab at 52 and 76 weeks. While reaching statistical significance, both trials observed a modest reduction in overall disease activity at 52 weeks and no significant benefit at 76 weeks. The benefit was largely due to improvements in musculoskeletal and cutaneous symptoms. ${ }^{52}$ Its role is in non-renal disease that is unresponsive to conventional drugs.

\section{Anifrolumab}

Anifrolumab blocks the interferon alpha receptor 1. Initial lupus studies observed benefits in disease activity. However, placebo-controlled trials (TULIP 1 and TULIP 2) failed to demonstrate benefit when conventional measures of lupus activity were used, and only marginally significant benefit when modified lupus scores were used. ${ }^{53,54}$

\section{Pregnancy}

Pregnancy can present challenges in women with lupus, so pregnancy planning and counselling are important..$^{55}$ Fertility rates are normal in lupus, unless compromised by cyclophosphamide ${ }^{56}$ or worsening renal failure. Recent evidence is conflicting regarding increased disease flares during pregnancy. ${ }^{57,58}$ However, the risks of pre-eclampsia ${ }^{59}$ and miscarriage ${ }^{60}$ are significantly higher. Secondary antiphospholipid syndrome confers added perinatal risk warranting specialist care.

When treating pregnant women, corticosteroids and azathioprine are generally safe. Mycophenolate, methotrexate and cyclophosphamide are contraindicated in pregnancy. Cyclophosphamide should be stopped three months before attempting to conceive and both men and women receiving cyclophosphamide should be on appropriate contraception. Egg harvesting or sperm banking should be considered before treatment.

\section{Conclusion}

Lupus has a wide range of clinical manifestations and should be considered as a diagnosis when two or more symptoms occur in women of childbearing age. All patients should receive hydroxychloroquine with appropriate monitoring. Antiproliferative drugs are useful for maintenance therapy, while high-dose steroids and cyclophosphamide are reserved for severe disease. The role of biologic drugs is an area of ongoing research. $<$

Conflict of interest: none declared

\section{REFERENCES}

1. Petri M, Orbai AM, Alarcón GS, Gordon C, Merrill JT, Fortin PR, et al. Derivation and validation of the Systemic Lupus International Collaborating Clinics classification criteria for systemic lupus erythematosus. Arthritis Rheum 2012;64:2677-86. https://doi.org/10.1002/art.34473

2. Sjöwall C, Sturm M, Dahle C, Bengtsson AA, Jönsen A, Sturfelt $\mathrm{G}$, et al. Abnormal antinuclear antibody titers are less common than generally assumed in established cases of systemic lupus erythematosus. J Rheumatol 2008;35:1994-2000.

3. Villalta D, Bizzaro N, Bassi N, Zen M, Gatto M, Ghirardello A, et al. Anti-dsDNA antibody isotypes in systemic lupus erythematosus: IgA in addition to IgG anti-dsDNA help to identify glomerulonephritis and active disease. PLoS One 2013;8:e71458. https://doi.org/10.1371/journal.pone.0071458

4. Arroyo-Ávila M, Santiago-Casas Y, McGwin G Jr, Cantor RS, Petri M, Ramsey-Goldman R, et al. Clinical associations of anti-Smith antibodies in PROFILE: a multi-ethnic lupus cohort. Clin Rheumatol 2015;34:1217-23. https://doi.org/ 10.1007/s10067-015-2941-y

5. Tektonidou MG, Laskari K, Panagiotakos DB, Moutsopoulos HM. Risk factors for thrombosis and primary thrombosis prevention in patients with systemic lupus erythematosus with or without antiphospholipid antibodies. Arthritis Rheum 2009;61:29-36. https://doi.org/10.1002/art.24232
6. Banchereau R, Hong S, Cantarel B, Baldwin N, Baisch J, Edens $\mathrm{M}$, et al. Personalized immunomonitoring uncovers molecular networks that stratify lupus patients. Cell 2016;165:1548-50. https://doi.org/10.1016/j.cell.2016.05.057

7. Kuhn A, Gensch K, Haust M, Meuth AM, Boyer F, Dupuy P, et al. Photoprotective effects of a broad-spectrum sunscreen in ultraviolet-induced cutaneous lupus erythematosus: a randomized, vehicle-controlled, double-blind study. J Am Acad Dermatol 2011;64:37-48. https://doi.org/10.1016/ j.jaad.2009.12.053

8. Jewell ML, McCauliffe DP. Patients with cutaneous lupus erythematosus who smoke are less responsive to antimalarial treatment. J Am Acad Dermatol 2000;42:983-7. https://doi.org/10.1067/mjd.2000.103635

9. Esdaile JM, Abrahamowicz M, Grodzicky T, Li Y, Panaritis C, du Berger $\mathrm{R}$, et al. Traditional Framingham risk factors fail to fully account for accelerated atherosclerosis in systemic lupus erythematosus. Arthritis Rheum 2001;44:2331-7. https://doi.org/10.1002/1529-0131(200110)44:10<2331::AIDART395>3.0.CO;2-1

10. Wallace DJ, Metzger AL, Klinenberg JR. NSAID usage patterns by rheumatologists in the treatment of SLE. J Rheumatol 1989;16:557-60.

11. Wang CR, Chuang CY, Chen CY. Drug allergy in Chinese patients with systemic lupus erythematosus. J Rheumatol 1993;20:399-400. 
12. Agus B, Nelson J, Kramer N, Mahal SS, Rosenstein ED. Acute central nervous system symptoms caused by ibuprofen in connective tissue disease. J Rheumatol 1990;17:1094-6.

13. Østensen M, Villiger PM. Nonsteroidal anti-inflammatory drugs in systemic lupus erythematosus. Lupus 2000;9:566-72. https://doi.org/10.1191/096120300678828794

14. Lai KM, Chen TL, Chang CC, Chen HH, Lee YW. Association between NSAID use and mortality risk in patients with end-stage renal disease: a population-based cohort study. Clin Epidemiol 2019:11:429-41. https://doi.org/10.2147/ CLEP.S204322

15. Kužnik A, Bencina M, Svajger U, Jeras M, Rozman B, Jerala R. Mechanism of endosomal TLR inhibition by antimalarial drugs and imidazoquinolines. J Immunol 2011;186:4794-804. https://doi.org/10.4049/jimmunol.1000702

16. Chasset $F$, et al. The effect of increasing the dose of hydroxychloroquine (HCQ) in patients with refractory cutaneous lupus erythematosus (CLE): an open-label prospective pilot study. J Am Acad Dermatol 2016;74:693-9. e693. https://doi.org/10.1016/j.jaad.2015.09.064.

17. Mok CC, Penn HJ, Chan KL, Tse SM, Langman LJ, Jannetto PJ. Hydroxychloroquine serum concentrations and flares of systemic lupus erythematosus: a longitudinal cohort analysis. Arthritis Care Res (Hoboken) 2016;68:1295-302. https://doi.org/10.1002/acr.22837

18. Cunha C, Alexander S, Ashby D, Lee J, Chusney G, Cairns TD, et al. Hydroxycloroquine blood concentration in lupus nephritis: a determinant of disease outcome? Nephrol Dial Transplant 2018;33:1604-10. https://doi.org/ 10.1093/ndt/gfx318

19. Wallace DJ, Linker-Israeli M, Metzger AL, Stecher VJ. The relevance of antimalarial therapy with regard to thrombosis, hypercholesterolemia and cytokines in SLE. Lupus 1993;2 Suppl 1:13-5. https://doi.org/10.1177/ 0961203393002001041

20. Broder A, Putterman C. Hydroxychloroquine use is associated with lower odds of persistently positive antiphospholipid antibodies and/or lupus anticoagulant in systemic lupus erythematosus. J Rheumatol 2013;40:30-3. https://doi.org/10.3899/jrheum.120157

21. Akhavan PS, Su J, Lou W, Gladman DD, Urowitz MB, Fortin PR. The early protective effect of hydroxychloroquine on the risk of cumulative damage in patients with systemic lupus erythematosus. J Rheumatol 2013;40:831-41. https://doi.org/10.3899/jrheum.120572

22. Alarcón GS, McGwin G, Bertoli AM, Fessler BJ, Calvo-Alén J, Bastian HM, et al.; LUMINA Study Group. Effect of hydroxychloroquine on the survival of patients with systemic lupus erythematosus: data from LUMINA, a multiethnic US cohort (LUMINA L). Ann Rheum Dis 2007;66:1168-72. https://doi.org/10.1136/ard.2006.068676

23. Easterbrook M. Is corneal deposition of antimalarial any indication of retinal toxicity? Can J Ophthalmol 1990;25:249-51.

24. Marmor MF, Kellner U, Lai TY, Melles RB, Mieler WF; American Academy of Ophthalmology. Recommendations on screening for chloroquine and hydroxychloroquine retinopathy (2016 revision). Ophthalmology 2016;123:1386-94. https://doi.org/ 10.1016/j.ophtha.2016.01.058

25. Hoes JN, Jacobs JW, Boers M, Boumpas D, Buttgereit F, Caeyers $\mathrm{N}$, et al. EULAR evidence-based recommendations on the management of systemic glucocorticoid therapy in rheumatic diseases. Ann Rheum Dis 2007;66:1560-7. https://doi.org/10.1136/ard.2007.072157

26. Singh JA, Saag KG, Bridges SL Jr, AkI EA, Bannuru RR, Sullivan MC, et al. 2015 American College of Rheumatology Guideline for the treatment of rheumatoid arthritis. Arthritis Rheumatol 2016:68:1-26. https://doi.org/10.1002/ art.39480

27. Soria A, Barbaud A, Assier H, Avenel-Audran M, Tétart F, Raison-Peyron N, et al.; FISARD (French Investigators for Skin Adverse Reaction to Drugs). Cutaneous adverse drug reactions with antimalarials and allergological skin tests. Dermatology 2015;231:353-9. https://doi.org/10.1159/ 000438787

28. Costedoat-Chalumeau N, Amoura Z, Duhaut P, Huong DL, Sebbough D, Wechsler B, et al. Safety of hydroxychloroquine in pregnant patients with connective tissue diseases: a study of one hundred thirty-three cases compared with a control group. Arthritis Rheum 2003:48:3207-11. https://doi.org/10.1002/art.11304
29. Zonana-Nacach A, Barr SG, Magder LS, Petri M. Damage in systemic lupus erythematosus and its association with corticosteroids. Arthritis Rheum 2000;43:1801-8. https://doi.org/10.1002/1529-0131(200008)43:8<1801::AIDANR16>3.0.CO;2-O

30. Liu D, Ahmet A, Ward L, Krishnamoorthy P, Mandelcorn ED, Leigh $\mathrm{R}$, et al. A practical guide to the monitoring and management of the complications of systemic corticosteroid therapy. Allergy Asthma Clin Immunol 2013;9:30. https://doi.org/10.1186/1710-1492-9-30

31. Magder LS, Petri M. Incidence of and risk factors for adverse cardiovascular events among patients with systemic lupus erythematosus. Am J Epidemiol 2012;176:708-19. https://doi.org/10.1093/aje/kws130

32. van Vollenhoven RF, Mosca M, Bertsias G, Isenberg D, Kuhn A, Lerstrøm K, et al. Treat-to-target in systemic lupus erythematosus: recommendations from an international task force. Ann Rheum Dis 2014;73:958-67. https://doi.org/ 10.1136/annrheumdis-2013-205139

33. Buttgereit F, da Silva JA, Boers M, Burmester GR, Cutolo M, Jacobs J, et al. Standardised nomenclature for glucocorticoid dosages and glucocorticoid treatment regimens: current questions and tentative answers in rheumatology. Ann Rheum Dis 2002;61:718-22. https://doi.org/10.1136/ard.61.8.718

34. Kuhn A, Ruland V, Bonsmann G. Cutaneous lupus erythematosus: update of therapeutic options part I. J Am Acad Dermatol 2011;65:e179-93. https://doi.org/ 10.1016/j.jaad.2010.06.018

35. Sakthiswary R, Suresh E. Methotrexate in systemic lupus erythematosus: a systematic review of its efficacy. Lupus 2014:23:225-35. https://doi.org/10.1177/0961203313519159

36. Ginzler EM, Wofsy D, Isenberg D, Gordon C, Lisk L, Dooley MA; ALMS Group. Nonrenal disease activity following mycophenolate mofetil or intravenous cyclophosphamide as induction treatment for lupus nephritis: findings in a multicenter, prospective, randomized, open-label, parallelgroup clinical trial. Arthritis Rheum 2010;62:211-21. https://doi.org/10.1002/art.25052

37. Ordi-Ros J, Sáez-Comet L, Pérez-Conesa M, Vidal X, Mitjavila F, Castro Salomó A, et al. Enteric-coated mycophenolate sodium versus azathioprine in patients with active systemic lupus erythematosus: a randomised clinical trial. Ann Rheum Dis 2017:76:1575-82. https://doi.org/ 10.1136/annrheumdis-2016-210882

38. Tunnicliffe DJ, Palmer SC, Henderson L, Masson P, Craig JC, Tong $\mathrm{A}$, et al. Immunosuppressive treatment for proliferative lupus nephritis. Cochrane Database Syst Rev 2018;6:CD002922. https://doi.org/10.1002/14651858.CD002922.pub4

39. Merrill JT, Neuwelt CM, Wallace DJ, Shanahan JC, Latinis KM, Oates JC, et al. Efficacy and safety of rituximab in moderately-to-severely active systemic lupus erythematosus: the randomized, double-blind, phase II/III systemic lupus erythematosus evaluation of rituximab trial. Arthritis Rheum 2010;62:222-33. https://doi.org/10.1002/ art. 27233

40. Rovin BH, Furie R, Latinis K, Looney RJ, Fervenza FC, Sanchez-Guerrero J, et al.; LUNAR Investigator Group. Efficacy and safety of rituximab in patients with active proliferative lupus nephritis: the Lupus Nephritis Assessment with Rituximab study. Arthritis Rheum 2012;64:1215-26. https://doi.org/10.1002/art.34359

41. Mysler EF, Spindler AJ, Guzman R, Bijl M, Jayne D, Furie RA, et al. Efficacy and safety of ocrelizumab in active proliferative lupus nephritis: results from a randomized, double-blind phase III study. Arthritis Rheum 2013;65:2368-79. https://doi.org/10.1002/art.38037

42. Schindler T, Rovin B, Furie R, Leandro M, Clark M, Brunetta J, et al. AB0 423 NOBILITY, a phase 2 trial to assess the safety and efficacy of obinutuzumab, a novel type 2 anti-CD20 monoclonal antibody (mAb), in patients (pts) with ISN/RPS class III or IV lupus nephritis (LN). Ann Rheum Dis 2016;75:1051. https://doi.org/10.1136/annrheumdis-2016-eular.2397

43. Navarra SV, Guzmán RM, Gallacher AE, Hall S, Levy RA, Jimenez RE, et al.; BLISS-52 Study Group. Efficacy and safety of belimumab in patients with active systemic lupus erythematosus: a randomised, placebo-controlled, phase 3 trial. Lancet 2011;377:721-31. https://doi.org/10.1016/ S0140-6736(10)61354-2 
44. Furie R, Petri M, Zamani O, Cervera R, Wallace DJ, Tegzová D, et al.; BLISS-76 Study Group. A phase III, randomized, placebo-controlled study of belimumab, a monoclonal antibody that inhibits B lymphocyte stimulator, in patients with systemic lupus erythematosus. Arthritis Rheum 2011;63:3918-30. https://doi.org/10.1002/art.30613

45. Isenberg D, Gordon C, Licu D, Copt S, Rossi CP, Wofsy D. Efficacy and safety of atacicept for prevention of flares in patients with moderate-to-severe systemic lupus erythematosus (SLE): 52-week data (APRIL-SLE randomised trial). Ann Rheum Dis 2015;74:2006-15. https://doi.org/ 10.1136/annrheumdis-2013-205067

46. Isenberg DA, Petri M, Kalunian K, Tanaka Y, Urowitz MB, Hoffman RW, et al. Efficacy and safety of subcutaneous tabalumab in patients with systemic lupus erythematosus: results from ILLUMINATE-1, a 52-week, phase III, multicentre, randomised, double-blind, placebo-controlled study. Ann Rheum Dis 2016;75:323-31. https://doi.org/10.1136/ annrheumdis-2015-207653

47. Merrill JT, van Vollenhoven RF, Buyon JP, Furie RA, Stohl W, Morgan-Cox M, et al. Efficacy and safety of subcutaneous tabalumab, a monoclonal antibody to B-cell activating factor, in patients with systemic lupus erythematosus: results from ILLUMINATE-2, a 52-week, phase III, multicentre, randomised, double-blind, placebo-controlled study. Ann Rheum Dis 2016;75:332-40. https://doi.org/10.1136/ annrheumdis-2015-207654

48. McBride JM, Jiang J, Abbas AR, Morimoto A, Li J, Maciuca R, et al. Safety and pharmacodynamics of rontalizumab in patients with systemic lupus erythematosus: results of a phase I, placebo-controlled, double-blind, dose-escalation study. Arthritis Rheum 2012;64:3666-76. https://doi.org/ 10.1002/art.34632

49. Terrier B, Amoura Z, Ravaud P, Hachulla E, Jouenne R, Combe B, et al.; Club Rhumatismes et Inflammation. Safety and efficacy of rituximab in systemic lupus erythematosus: results from 136 patients from the French Autolmmunity and Rituximab registry. Arthritis Rheum 2010;62:2458-66. https://doi.org/10.1002/art.27541

50. laccarino L, Bartoloni E, Carli L, Ceccarelli F, Conti F, De Vita S, et al. Efficacy and safety of off-label use of rituximab in refractory lupus: data from the Italian Multicentre Registry. Clin Exp Rheumatol 2015;33:449-56.
51. Mackay F, Woodcock SA, Lawton P, Ambrose C, Baetscher M, Schneider P, et al. Mice transgenic for BAFF develop lymphocytic disorders along with autoimmune manifestations. J Exp Med 1999;190:1697-710. https://doi.org/ 10.1084/jem.190.11.1697

52. Manzi S, Sánchez-Guerrero J, Merrill JT, Furie R, Gladman D, Navarra SV, et al.; BLISS-52 and BLISS-76 Study Groups. Effects of belimumab, a B lymphocyte stimulator-specific inhibitor, on disease activity across multiple organ domains in patients with systemic lupus erythematosus: combined results from two phase III trials. Ann Rheum Dis 2012;71:1833-8. https://doi.org/10.1136/annrheumdis-2011-200831

53. Furie RA, Morand EF, Bruce IN, et al. Type I interferon inhibitor anifrolumab in active systemic lupus erythematosus (TULIP-1): a randomised, controlled, phase 3 trial. Lancet Rheumatol 2019;1:e208-19. https://doi.org/10.1016/ S2665-9913(19)30076-1

54. Morand EF, Furie R, Tanaka Y, Bruce IN, Askanase AD, Richez C, et al.; TULIP-2 Trial Investigators. Trial of anifrolumab in active systemic lupus erythematosus. N Engl J Med 2020;382:211-21. https://doi.org/10.1056/NEJMoa1912196

55. Paizis K. Immunomodulatory drugs in pregnancy and lactation. Aust Prescr 2019;42:97-101. https://doi.org/ 10.18773/austprescr.2019.026

56. Langevitz P, Klein L, Pras M, Many A. The effect of cyclophosphamide pulses on fertility in patients with lupus nephritis. Am J Reprod Immunol 1992;28:157-8. https://doi.org/10.1111/j.1600-0897.1992.tb00780.x

57. Wong KL, Chan FY, Lee CP. Outcome of pregnancy in patients with systemic lupus erythematosus. A prospective study. Arch Intern Med 1991;151:269-73. https://doi.org/ 10.1001/archinte.1991.00400020043010

58. Urowitz MB, Gladman DD, Farewell VT, Stewart J, McDonald J. Lupus and pregnancy studies. Arthritis Rheum 1993;36:1392-7. https://doi.org/10.1002/art.1780361011

59. Julkunen H, Kaaja R, Palosuo T, Grönhagen-Riska C, Teramo K. Pregnancy in lupus nephropathy. Acta Obstet Gynecol Scand 1993;72:258-63. https://doi.org/ 10.3109/00016349309068034

60. Nossent HC, Swaak TJ. Systemic lupus erythematosus. $\mathrm{VI}$. Analysis of the interrelationship with pregnancy. Rheumatol 1990:17:771-6. 